This item was submitted to Loughborough's Research Repository by the author.

Items in Figshare are protected by copyright, with all rights reserved, unless otherwise indicated.

\title{
Rewriting Tarr ten years later: Wyndham Lewis, the Phoenix Library and the domestication of modernism
}

PLEASE CITE THE PUBLISHED VERSION

http://www.wyndhamlewis.org/

\section{PUBLISHER}

Wyndham Lewis Society

\section{VERSION}

AM (Accepted Manuscript)

\section{PUBLISHER STATEMENT}

This work is made available according to the conditions of the Creative Commons Attribution-NonCommercialNoDerivatives 4.0 International (CC BY-NC-ND 4.0) licence. Full details of this licence are available at: https://creativecommons.org/licenses/by-nc-nd/4.0/

\section{LICENCE}

CC BY-NC-ND 4.0

\section{REPOSITORY RECORD}

Jaillant, Lise. 2019. "Rewriting Tarr Ten Years Later: Wyndham Lewis, the Phoenix Library and the Domestication of Modernism”. figshare. https://hdl.handle.net/2134/20563. 


\section{Rewriting Tarr Ten Years Later: \\ Wyndham Lewis, the Phoenix Library, and the \\ Domestication of Modernism}

[winner of the 2014 Wyndham Lewis

Memorial Trust Essay Prize]

Lise Jaillant

Four years before his death, Wyndham Lewis wrote to the modernist scholar Hugh Kenner: 'In Tarr I had in view a publique d'élite who could be addressed in blank verse, and the style of the poème en prose might suddenly be used, or be employed for half a page. Down to Fielding or Thackeray in England, and in all the great Russian novelists it was an aristocratic audience which was being addressed.' Lewis added: 'In Tarr (1914-15) I was an extremist' (L 552). This image of a difficult, uncompromising novel for an élite could well apply to the first version of Tarr - completed in 1915 and published by the Egoist Press in Britain and by Knopf in the United States in 1918. But in 1928, Lewis accepted an offer to reprint his novel in the newly created Phoenix Library, sold for only 3 shillings and 6 pence. Lewis was reluctant at first, complaining about the low compensation he would receive. But he then threw himself into the project and decided to re-write the entire novel. At that time in his career, Lewis was eager to address not a 'publique d'élite' or an 'aristocratic audience', but a large audience who had never read Tarr before.

Scholars have often discussed the merit of the 1928 edition over the earlier versions. 'Just ask any one of the two dozen Lewis scholars in the world which of the versions of Tarr is the best or most complete text', wrote John Xiros Cooper. 'Be prepared for a lively response.' While some might prefer the less polished Egoist or Knopf texts, it is likely that very few university teachers choose these versions for their courses. When Scott W. Klein edited a reprint edition of Tarr in the Oxford World's Classics series, he selected the 1928 text. As he put it: 
'Lewis intended Tarr to be known solely in its revised version' (T2 xxxii). Although the differences between the 1918 and 1928 texts have been extensively studied, the Phoenix Library is mentioned only in passing (if at all). ${ }^{2}$ This gap in scholarship is all the more surprising given that Lewis self-consciously recorded his engagement with the publisher's series. "This is the copy of the american edition of "Tarr" on which I made the corrections for the revised edition of "Tarr" published in Chatto \& Windus' "Phoenix" library.' This inscription in Lewis's hand, dated April 1929, appears on the title page of the Knopf edition of Tarr held at the University at Buffalo. ${ }^{3}$ While Lewis scholars have largely neglected the Phoenix Library, book historians have paid more attention to this series. Andrew Nash rightly notes that the republication of Tarr 'marks a moment of transferral of a text from a small, elite readership to

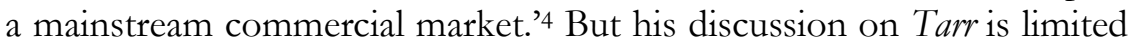
to one paragraph in a chapter that focuses on various aspects of interwar publishing in Britain. Nash also briefly mentions Tarr in an interesting essay on the Phoenix Library. ${ }^{5}$

In this essay, I want to replace the Phoenix Library at the centre of the discussion on the 1928 Tarr. I propose to examine the revised version as a material artefact as well as a stylistic testimony on the 'taming' of modernism. Writing for the large audience that would read his novel in a cheap format, Lewis made his style much more accessible and less confusing for the common reader. Tarr is therefore a prime example of the late 1920s domestication of an earlier, utopian modernist form. Drawing on archival research in the Chatto \& Windus records at the University of Reading, I take the example of Tarr to argue that the Phoenix Library not only made available modernism to a much wider audience, but also transformed the modernist text itself. The first section of this essay briefly examines the genesis and publication of the ur-Tarr. The second part looks at the creation of the Phoenix Library and its role in the diffusion of modernism. The third section focuses more specifically on the inclusion of the revised Tarr in the series in 1928. The final part sheds light on the advertising, distribution, and reception of this cheap edition, an edition that reached a much wider audience than the 1918 texts. 


\section{The Three 'First' Tarrs}

In 1915, the thirty-three-year-old Wyndham Lewis finished Tarr, a satire of bohemian life in Paris. In his autobiography Blasting and Bombardiering (1937), Lewis presented the period 1914-1915 as a high point in his career as painter and writer. The first issue of the provocative little magazine BLAST, published just before the declaration of war, had attracted a great deal of attention. As the leader of the Vorticist movement, Lewis was 'on constant exhibition': 'Everyone by way of being fashionably interested in art, and many who had never opened a book or brought so much as a sporting-print, much less "an oil", wanted to look at this new oddity, thrown up by that amusing spook, the Zeitgeist' ( $B B$ 46). Lewis probably exaggerated his popularity. In Institutions of Modernism (1998), Lawrence Rainey argues that 'contemporary critics were neither angered nor provoked by Blast. They were simply bored, and not because Blast was an incomprehensible novelty, but because it was all too familiar.' ${ }^{6}$ For Rainey, Vorticism was generally seen as a pale imitation of Futurism, led by the charismatic Filippo Marinetti. Even Lewis admitted that the invitations he received brought him little rewards, financial or otherwise: 'As a result of these sociable activities I did not sell a single picture' (BB 47).

Lewis also had trouble finding a publisher for Tarr, a novel that deals with casual sex, rape, murder, and suicide. In late November 1915, John Lane, who had published BLAST, rejected Tarr, for being 'too strong a book' ( $L$ 74). The novel was then turned down by another publisher, Werner Laurie, before being accepted by Harriet Shaw Weaver, who serialized it in the little magazine The Egoist from April 1916 to November 1917. Lewis, who had joined the army, asked his friend Ezra Pound to prepare a publishable text of Tarr for the American edition. As Paul O'Keeffe notes, Pound's 'task was made difficult because parts of the original typescript, edited down for serialisation, had apparently gone astray at The Egoist's printers in West Norwood. As a result he was forced to plug gaps with printed pages from the September 1916, February, April and June 1917 issues of The Egoist.' ${ }^{3}$ The American edition was published by Alfred Knopf in June 1918, shortly before it appeared in England under The Egoist imprint. As John Xiros Cooper puts it, 'there were three "first" Tarrs, all of them different. ${ }^{8}$ 
Even by the standards of small-scale institutions of modernism (little magazines and small presses), Tarr was not a commercial success. Harriet Shaw Weaver, who paid $£, 50$ for the serialization rights, 'still had a $£ 36$ deficit in 1924 '. ${ }^{9}$ For the publication in book form (priced at 6 shillings), Weaver refused to pay any royalties until her costs had been covered. She sold 729 copies of the book out of a first printing of 1,000, and lost $f^{22.10}$ It is unlikely that the Knopf edition, priced at $\$ 1.75$, sold much more than the Egoist edition, and no cheap reprint of Tarr appeared in the United States during Lewis's lifetime. ${ }^{11}$ Although the first versions of Tarr reached a small number of readers, the critical reception was generally enthusiastic. Tarr was praised by young critics, including Ezra Pound, Rebecca West, and T. S. Eliot. 'There can be no question of the importance of Tarr', wrote Eliot in the Egoist. 'In the work of Mr. Lewis we recognize the thought of the modern and the energy of the cave-man.' ${ }^{12}$ A press release issued by Harriet Shaw Weaver shows that positive reviews appeared not only in little magazines, but also in the mainstream press (including The Times, The Morning Post, The Manchester Guardian and The Glasgow Herald. ${ }^{13}$ Many people had heard of Tarr, but never read the book - which was only available in relatively expensive editions published by small presses.

In the 1920s, Lewis suffered setbacks that threatened his position in the artistic world. As Paul Edwards points out, 'his Tyros and Portraits exhibition made little impact, his money ran out, and he failed to complete the necessary complement of advanced experimental works needed for a projected show in Léonce Rosenberg's gallery L'Effort Moderne in Paris. ${ }^{14}$ Lewis deeply resented his growing dependence on the patronage of friends and art collectors. His career as a writer was also in decline. Having published no books between 1919 and 1926, he was being eclipsed by the other 'men of 1914', James Joyce and T. S. Eliot. It was not until the late 1920s that Lewis staged a comeback. In 1926, his new publisher, Chatto \& Windus, issued The Art of Being Ruled. This was the start of a long collaboration with Charles Prentice, the senior partner at the firm. Encouraged by Prentice, Lewis became increasingly productive. 'The year 1927 was Lewis' annus mirabilis', notes Jeffrey Meyers. 'He published The Lion and the Fox, his Machiavellian interpretation of Shakespeare's tragedies, in January; the first number of the Enemy, his third magazine, in February; Time and Western Man, his most important non-fictional work, in September; the second number of the Enemy in September; and The Wild Body, his thoroughly revised 
comic stories of Brittany, in November.' ${ }^{15}$ It is in this context of renewed artistic activity that Prentice offered to reprint Tarr in the Phoenix Library.

\section{The Phoenix Library and the Diffusion of Modernism}

Charles Prentice was then a young publisher who had worked at Chatto $\&$ Windus since the end of the War. When Prentice was away fighting in France, his father - a well-known Scottish solicitor - had bought him a partnership at the firm. Prentice was in charge of book design until 1926, when he became senior partner. In their essay on the writer T. F. Powys and Chatto \& Windus, Andrew Nash and James Knowlson describe Prentice as a 'remarkable publisher' who gave 'support and advice, inspiration and friendship' to many authors, including Wyndham Lewis, Samuel Beckett, Norman Douglas, David Garnett, Richard Hughes, Sylvia Townsend Warner, and Richard Aldington. ${ }^{16}$ Prentice also frequently corresponded with Aldous Huxley, whose successful association with Chatto \& Windus began in $1920 .{ }^{17}$ By the end of the decade, the firm decided to publish its backlist of Huxley's books in a uniform, cheap series of reprints. 'We are launching [the Phoenix Library] at the end of January [1928]', Prentice wrote to Huxley. 'It is a sort of Pocket library at 3/6d., more or less the same kind of thing as Secker's Adelphi Library and Cape's Traveller's [sic] Library.'18 Like these two inexpensive series, the Phoenix Library would include copyrighted texts published in a distinguished but small format.

The Phoenix Library departed from its competitors in at least two aspects. First, Chatto \& Windus could rely on its prestigious backlist, which included books by Huxley but also Lytton Strachey, Arnold Bennett, C. E. Montague, and others. Moreover, well-known writers would each be associated with a distinctive colour in binding. As the firm told the literary agent Eric Pinker, Huxley and Montague would 'retain an individuality of their own, but at the same time get the advantages which such a series gives to books within it." ${ }^{19}$ Books by Montague were thus bound in red cloth, Huxley in blue, and Strachey in green. In short, the Phoenix Library combined two seemingly contradictory marketing strategies: an emphasis on the distinctiveness of selected authors but also an insistence on the uniformity of the series. 
Apart from the colour of their binding, all Phoenix Library books looked the same and were sold for the same price (a more expensive leather edition was soon abandoned). 20 The illustrator Thomas Derrick (1885-1954) designed the uniform dust jacket. Educated at the Royal College of Art, where he exhibited his work and later became an instructor of decorative painting for five years, Derrick had a varied artistic production. His work included murals, stained glass, portraiture, posters for the London Underground, and artwork in publications such as Punch. ${ }^{21}$ The wrapper he designed for the Phoenix Library was bright red, a colour that, 'owing to a novel process', would 'not easily fade.'22 As Chatto \& Windus explained to the editor of The Times Literary Supplement, 'the publishers believe that, by the devise [sic] of using, as here, printers' ink instead of stationers' dye they have produced dustcovers that are more likely to wear well than any others of a similar series now on the market. ${ }^{23}$ In addition to differentiating the Phoenix Library from its competitors, the jacket served to unify the series. Once wrapped, each Phoenix Library book looked the same (in spite of their bindings in various colours). As Chatto \& Windus explained to Pinker, 'a mass of uniform colour on a bookseller's shelf catches the eye, and thus attracts purchasers' (fig. 1).24

In addition to the dustcover, Derrick designed the emblem of the series, the Phoenix. In a discussion of the Modern Library's own emblem (a torchbearer figure), Jay Satterfield notes: 'The colophon's twentieth-century revitalization as a quality trademark was symptomatic of literature's commodification, although it drew on a tradition of fine printing consciously detached from commercial interests by its aesthete progenitors. ${ }^{25}$ Likewise, the Phoenix Library's colophon increased the cultural capital of the series while also serving as a distinctive trademark - appearing on dust jackets, covers, title-pages, and advertisements (figs 2 and 3a). Chatto \& Windus explicitly described the Phoenix as 'the symbol of rebirth' - a fitting emblem for a series of modern literature. ${ }^{26}$ As Andrew Nash puts it, 'the ornithological image anticipates the success of the Penguin paperbacks, which would hatch less than a decade later.' ${ }^{27}$ Derrick also designed the gold decorations on the binding cases. The Phoenix Library's high standard of production was coherent with Chatto \& Windus's distinguished reputation for the quality of their book design.

Like other publisher's series, the Phoenix Library included a wide range of texts: bestselling novels by Lytton Strachey, Aldous Huxley, 
Richard Aldington, and David Garnett; plays by A. A. Milne and Richard Hughes; popular science (including several titles by Julian Huxley); political essays; and even a cookery book. As Prentice told the co-author of The Gentle Art of Cookery, a Phoenix Library edition of the book would have a good chance of capturing the cultivated and educated public to which it primarily appeals - whereas in a fat form at 3s. 6d. it would be jostled and jumbled between Mrs. Beeton, Good Housekeeping, The Olio Book etc. etc. etc.'28 In other words, the Phoenix Library would raise The Gentle Art of Cookery above its competitors - as a well-written text for a sophisticated audience. 'You may wonder why on earth we are including a cookery book in such a literary assembly', wrote Harold Raymond (the firm's other senior partner) to one colleague. You will see that the book has a decided literary savour, and I do assure you that any number of the recipes have a savour that is more than literary.'29 Here, the repetition of 'literary' highlights a key aspect of the marketing of the series - the fact that the Phoenix Library was sold as a distinguished series for all those who could not, or would not, pay more than 3 shillings and 6 pence for a book.

The Phoenix Library also included modernist titles that had so far been restricted to a small audience. As Chatto \& Windus told Roger Fry, 'by an inclusion in the library Vision and Design stands a chance of reaching a wider public than that definitely concerned with the study of aesthetics. '30 In 1928 and 1929, Clive Bell's Art and Since Cézanne as well as Fry's Vision and Design were reprinted in the series and sold to a large readership, thus raising awareness of recent developments in modern art. The firm printed 5,000 copies of Since Cézanne in June 1929; 8,000 copies of Vision and Design between February 1928 and September 1929; and 10,000 copies of Art between December 1927 and December 1930. ${ }^{31}$ These figures show that books on modern art could sell as well, or even better, than a cookery book such as The Gentle Art of Cookery (8,000 copies were printed in the first six years after publication). .32

In addition to popularizing modern art, the Phoenix Library opened up new markets for the new poetry. The first anthology of poems published in the series was Twentieth-Century Poetry, edited by the poet and bookseller Harold Monro, who was closely associated with the modernist movement. In his monthly Poetry Review (launched in 1912), Monro had published Ezra Pound's manifesto 'Prolegomena' and F. S. Flint's study of recent French poetry, 'two contributions which gave rise to Pound's brief imagist movement.'33 Monro was also friendly with 
Wyndham Lewis, whose Rebel Arts Centre was just round the corner from his Poetry Bookshop. ${ }^{34}$ The bookshop was a well-known meeting place for poets in the 1910s and 1920s - including T. S. Eliot and his Criterion club. In his introduction to the Phoenix Library anthology, Monro predicted that Eliot would be a very influential figure 'up to 1940'.35 Poets represented in the anthology included Eliot, Pound, H.D., and W. B. Yeats, as well as Siegfried Sassoon and Wilfred Owen. ${ }^{36}$ In a letter to Monro, Pound noticed a 'good strong antimilitarist vein' in the anthology. ${ }^{37}$

Monro's anthology was widely reviewed - including in massmarket newspapers. 'Easily the best of the anthologies of modern verse is Twentieth Century Poetry [...] chosen by Harold Monro, himself a poet of rare distinction', declared The Morning Post. 'It is not an anthology compiled from anthologies, but the product of a wide and diligent investigation of all the original sources.' ${ }^{38}$ In a long review published in The Evening Standard, the influential critic Arnold Bennett wrote that although he could not understand the influence of T. S. Eliot on younger poets, he had been 'much impressed by Twentieth Century Poetry':

I read it with increasing respect and pleasure [...] on the whole its contents are surprisingly beautiful. There are more good poets around than I had supposed. Twentieth Century Poetry is the best anthology of the moderns that I have seen. It ought to sell. If it sells it will be talked about. If it is talked about, the cause of poetry will be advanced. ${ }^{39}$

It is likely that this review (which was reproduced in other newspapers, including The Liverpool Echo and The Manchester Evening News) contributed to the commercial success of the book. ${ }^{40}$ When Prentice contacted Monro about the anthology project, he warned him: 'there is not much money in the idea for either of us, unless the sales go beyond the 10,000 mark.'41 Twentieth-Century Poetry sold much more than that. As the Chatto \& Windus stock book shows, a total of 27,500 copies were printed in the three years following publication. ${ }^{42}$ This edition 'was followed in 1933 by a new edition revised and enlarged by Alida Monro, of which there have again been four reprints, the final issue being in 1950. ${ }^{43}$

Chatto \& Windus was not the first commercial publisher to realize that modernism could be marketed to a wide audience. In 1926, James Joyce's Dubliners was one of the first titles to appear in Cape's 
Travellers' Library. By 1928, even the conservative Oxford World's Classics included introductions by T. S. Eliot and Virginia Woolf. As a latecomer in the field of $3 / 6$ quality series, Chatto \& Windus had to create a list significantly different from its competitors. One way of doing that was to include daring books that would be talked about. The Phoenix Book Company, which sold the Phoenix Library directly to customers, ${ }^{44}$ used the vocabulary of class and taste to describe the series as an 'aristocrat among pocket libraries':

Its very format exhales the spirit which animates its editors in their selective pursuit. Aldous Huxley, Lytton Strachey, J. B. S. Haldane, Roger Fry - the PHOENIX LIBRARY is noted for its lively presentation of the modern attitude to life. Many of its books have created (and still create) world-wide discussions and acrid controversy. 45

To a large extent, the Phoenix Library can be seen as a British equivalent to the Modern Library - a series that had always specialized in controversial modern literature. This positioning was rather surprising, in view of Chatto \& Windus's reputation as a respectable 'list' publisher. ${ }^{46}$ As Nash and Knowlson point out, Charles Prentice 'was a kind, sensitive man who disliked any kind of controversy, let alone the deep hostilities involved in legal disputes' ${ }^{47}$ Yet under Prentice's leadership, the Phoenix Library published modern books that were then considered daring and controversial, including Richard Aldington's Death of a Hero and Lewis's Tarr.

\section{Tarr in the Phoenix Library}

It is possible that Prentice decided to reprint Tarr after reading a review by Arnold Bennett, which appeared in The Evening Standard in April 1927. 'Tarr had good chapters - chapters that were worth writing', wrote Bennett. 'It was, however, in the somewhat Teutonic lump, doughy, and at last unreadable.' 48 In a long response to the editor of The Evening Standard, Lewis openly presented himself as Bennett's enemy. ${ }^{49}$ This controversy in a mass-market newspaper was a great publicity coup for Lewis. Yet, those readers who wanted to check if Tarr was, indeed, 'unreadable' would have had great difficulty finding a copy of the book. 
In spring 1928, when Prentice suggested including Tarr in the Phoenix Library, he probably thought that it would be a straightforward matter. Surely, the impoverished Lewis would be glad to receive a check - however small - for a novel that The Egoist Press had remaindered long ago. However, Prentice's offer of $£ 150$ for the outright sale of Tarr infuriated Lewis:

This can only mean (1) that is an unsatisfactory offer or (2) that your firm is disappointed with its author: as I cannot entertain the first alternative I am compelled to believe the second and that I find very discouraging. As I am hard-up I must sell Tarr now and 300 pounds for an outright sale of that book is not, I feel, out of the way. 250 pounds is the lowest that [?] in the present circumstances I shall be able to accept for an outright sale. Considered as an advance on royalties I do not see [...] that for Tarr I could just now fix the figure lower than 200 pounds - for that could imply that I considered Tarr worth less today than a book of collected stories one year ago. I may add that were I not in need of money I wouldn't part with Tarr for that figure or contemplate an outright sale at all. ${ }^{50}$

As the first section of Lewis's Childermass had just been published, Lewis felt 'particularly dejected' that his new novel was coming out in 'this atmosphere of disappointment.' Lewis had high hopes for The Childermass, a novel marketed as an ambitious book that would rival Joyce's Ulysses. ${ }^{51}$ His bargaining over Tarr sheds light not only on his financial difficulties, but also on his conviction that his first novel was central to his career and, more generally, to the modernist movement. This explains why Lewis took the trouble of entirely rewriting the novel once an agreement was reached with Chatto \& Windus. 'I should be sorry to have gone down to posterity as "the author of Tarr" in its unrevised first version', declared Lewis (BB 86).

In an effort to obtain better terms for Tarr, Lewis suggested that Chatto \& Windus issue a more expensive edition first - a proposal that Prentice rejected:

There would be no real market for a 7/6 reissue; such a reissue would only prevent and delay the book's chances in a cheaper form. The best course therefore is to publish at 3/6 straight away. 
You asked us to make you an outright offer for the English book rights. We could only publish at $3 / 6$, we offered $f 150$. This amounts to very nearly the sale of 10,000 copies on a $10 \%$ royalty, which (even on books that have not to be reset) is the recognised royalty on such editions, except in the case of those books that sell very/ very quickly in huge numbers. I have asked our town traveller how long he thinks it would take us to sell these 10,000 copies. He puts it at a minimum of 5 to 6 years, and on this basis and considering there will be the extra expense of setting, I do not think this is a mean price. What might happen after 5 or 6 years is a pure gamble. 52

This letter sheds light on the publisher's cautious strategy for Tarr, a novel that had sold fewer than 800 copies in its first British edition. While Lytton Strachey's bestsellers Queen Victoria and Eminent Victorians had first printings of 10,000 copies in the Phoenix Library, Tarr was a more difficult and controversial novel. 'The public must be remembered', wrote Prentice, 'and with books of the originality of yours it does take time to obtain a wide public, for which alone large circulations can be expected. ${ }^{53}$ For Prentice, the 10,000 mark could be reached only when the public had been educated to appreciate the originality of Tarr's modernist style.

Once again, Lewis rejected Prentice's offer of $£ 150$ for an outright sale or $£, 75$ as an advance on royalties. As Lewis recognized, Chatto \& Windus had attributed to him 'an important place in its lists' and 'obviously taken great trouble in pushing [his] books' (L 177-78). Yet the offer was too low to leave him enough time to write other books. 'I must throw Tarr upon the market and wait till it finds a purchaser', declared Lewis - implying that Chatto \& Windus was not the only publisher interested in his first novel. The fact that Prentice did increase his offer proves that Lewis was right to present Tarr as valuable property. The contract signed on 29 May 1928 shows that Lewis received an advance on royalties of $£ 150$, half of that amount for Tarr and the other half for other books Chatto \& Windus would publish. ${ }^{54}$ This arrangement limited the risks of publishing Tarr: if the novel sold fewer than 5,000 copies, the firm would lose less than $f^{75}$ (the amount initially offered by Prentice).

Shortly after signing the agreement, Lewis announced his intention to make extensive revisions to the novel. As we have seen, he 
did not want to be remembered as the author of a novel that had been hastily written, and hastily put together for publication while he was away fighting in the War. Moreover, Lewis was no longer satisfied with the style of the 1918 Tarr, a style that Cooper has described as profoundly violent:

Hairline fractures in the syntax of the sentences and the syntax of the succession of sentences, unconventional stops and starts, including the invention of the equal sign $(=)$ as a new mark of punctuation, stark juxtapositions, the elimination of the usual conjunctive tissue in the context of a standard English prose, were the stylistic means he employed to carry out the assault. They were all aimed at bringing the flow of narrative continuity and the reading process itself into moments of violent arrest, into moments of crisis or undecidability. 55

In 1928, Lewis decided to polish his antagonistic style for the larger audience that would read Tarr in the Phoenix Library. 'I have throughout finished what was rough and given the narrative everywhere a greater precision', he wrote in the new preface..$^{56}$

Lewis's revisions downplayed the experimental nature of the earlier version and improved its readability. Let's take an example from Chapter 1, when Tarr explains his philosophy to a fellow bohemian, Hobson. In the earlier version, Tarr's logorrhoea has the chaotic energy of BLAST:

"Sex is a monstrosity. It is the arch abortion of this filthy universe. = How 'old-fashioned!' - eh, my fashionable friend? = We are all optimists to-day, aren't we? God's in his Heaven, all's well with the world! How robust! How manly! how pleasant, and above all, how desirable! It's a grand place, isn't it? Full of white men, strong men, super men; 'great statesmen,' 'great soldiers,' 'great artists,' 'sacred faith,' 'noble pity,' 'sacrifice,' 'pure art,' 'abstract art,' 'civilisation' and stuff. = You positively, when you think of it all, feel like dropping on your knees in a gush of gratitude to God! But I'm a new sort of pessimist. = I think I am the sort that will please! = I am the Panurgic-Pessimist, drunken with the laughing gas of the Abyss. I gaze on squalor and idiocy, and the more I see it, the more I like it. = Flaubert built up his 
Bouvard and Pécuchet with maniacal and tireless hands. It took him ten years. That was a long draught of stodgy laughter from the gases that rise from the dung-heap? He has an appetite like an elephant for this form of mirth. But he grumbled and sighed over his food. = I take it in my arms and bury my face in it!" (T1 2627)

In the revised version, the double hyphen has disappeared, and Tarr's monologue has been divided into shorter, more readable bits:

"Sex is a monstrosity. Sex is a monstrosity. It's the last and ugliest piece of nonsense of a long line. I can see you raising your eyebrows. No? You should do so: I'm a pessimist -."

"A german pessimist!"

"A pessimist. I'm a new sort of pessimist. I think I'm the sort that will go down."

"Why not? But you must -."

"No! I am the panurgic-pessimist, drunken with the laughing-gas of the Abyss: I gaze upon squalor and idiocy, and the more I see them the more I like them. Flaubert built up his Bouvard and Pécuchet with maniacal and tireless hands, it took him ten years: that was a long draught of stodgy laughter from the gases that rise from the dung-heap."

"Flaubert -."

"No" (Tarr raised his flat hand, threatening Hobson's mouth) "he had an appetite like an elephant for this form of mirth, but he grumbled and sighed over his food. I take the stuff up in my arms and bury my face in it!” (T2 13)

There is certainly a case to be made for the 1918 version as a more exciting novel. But my objective here is not to judge the literary value of the text. Instead, I want to show that Lewis revised his novel for a specific audience - an audience unfamiliar with the asperities of earlier modernist forms.

If Charles Prentice had been the same kind of publisher as Alfred Harcourt, he would probably have encouraged Lewis's decision to tame his modernist style. When Harcourt, Brace and Company issued Virginia Woolf's Orlando and Gertrude Stein's The Autobiography of Alice B. Toklas, advertisements insisted that these books were written in an easily- 
readable style. ${ }^{57}$ In other words, Woolf and Stein were presented as previously difficult modernist writers who could now reach a wide public. After the Autobiography's success, Harcourt reluctantly agreed to take on The Making of Americans, but only in an abridged version. Unlike Harcourt, Prentice believed that even experimental texts could sell well. As he told Lewis: 'I do not fancy you have really very much to do, that is, unless you decide to rewrite the book, which I do not think either necessary or desirable. "Tarr already is the best novel in the English language" (Who said this?); and it is always better to go on to things new and better still. ${ }^{58}$ Prentice anticipated that Tarr would sell between 5,000 and 10,000 copies, and there was simply no point revising it. As Sections II and III of The Childermass were scheduled to be published later in 1928, the publisher wanted Lewis to focus on his new work and avoid any delays. ${ }^{59}$

Although the revisions of Tarr were an initiative of the author rather than his publisher, this re-writing nevertheless exemplifies the impact of the publishing format on the modernist text. Had Tarr been reissued in an expensive limited edition, it is not sure that Lewis would have bothered revising the novel. There would have been no point 'finish[ing] what was rough' for a small coterie of readers already familiar with his avant-garde style. The Phoenix Library, on the contrary, would reach a new readership foreign to modernist experimentations. While Arnold Bennett had described the 1918 Tarr as 'unreadable', the revised version was meant to be palatable to this new audience.

Ironically, Tarr was released at the same time as the Phoenix Library edition of Bennett's The Grim Smile of the Five Towns. These two books had been 'for some time out of print', as the firm told F. A. Mumby of The Times Literary Supplement. ${ }^{60}$ Lewis's novel was number 27 in the series, Bennett's book number 26, and Aldous Huxley's Little Mexican and Other Stories number 28. The fact that Tarr appeared alongside novels by such well-known names as Bennett and Huxley undoubtedly increased its appeal. The series made no distinction between Lewis and his arch-enemy Arnold Bennett and encouraged readers to collect all Phoenix Library books. ${ }^{61}$

The publication of Tarr was announced for November 1928, but Lewis took longer than expected to revise the novel. In late August, he wrote to his publisher: 'I am very sorry to say that it has been impossible for me during the last 3 weeks to devote myself to the correcting of the last 200 pages of Tarr, but I am now about to do so.' ${ }^{2}$ By mid- 
November, Lewis had finished revising the corrected proofs, and had written a new preface. The book, published with a bright orange cover on 12 December 1928, had a first printing of 5,250 copies. ${ }^{63} \mathrm{~A}$ second printing of 3,000 copies was ordered in February 1935, as the Phoenix Library celebrated its $100^{\text {th }}$ title (fig. 3b). Of this reprint, 1,460 copies were bound with cancel titles in July 1941 and published in the Pelham Library series at 4 shillings. ${ }^{64}$ In total, the cheap edition of Tarr sold approximately ten times more copies than The Egoist Press edition.

\section{Advertising, Distributing, and Reviewing Tarr}

To sell Tarr to a large audience, Chatto \& Windus emphasized the unique story of the book. As figure 2 shows, the uniform red dust jacket included a wrap-around band with the following text:

TARR, in a sense the first book of a period in England, and Mr. Wyndham Lewis's first book and first work of fiction, was originally published in 1918. For some time it has been out of print and copies have been procurable only at a premium. It has now been revised, and the new version is here presented for the first time to the public.

It was highly unusual for a reprints series to include a wrap-around band, especially one which emphasized the qualities of a specific book (rather than the series as a whole). But for Chatto \& Windus, Tarr's fascinating publishing and textual history could be used to create a desirable product. As the firm's narrative made clear, the book had the aura of an early moment of modernism. Like other modernist landmarks first published in limited editions, the 1918 Tarr was 'procurable only at a premium', restricting its appeal to a small elite. The Phoenix Library promised customers that they, too, could join this elite without spending more than 3 shillings and $6 \mathrm{~d}$.

Unlike small presses, Chatto \& Windus could spend large amounts on advertising. Between December 1928 and June 1929, Tarr was mentioned in five advertisements in The Times Literary Supplement alone. ${ }^{65}$ These ads can be classified in three categories. The first kind, which appeared shortly after the publication of Tarr, focused on new Chatto \& Windus titles, rather than on the Phoenix Library. 'Mr. 
WYNDHAM LEWIS has also completely revised and expanded his magnificent novel', declared one ad. 'It is virtually a new book, of firstrate importance. ${ }^{66}$ In an attempt to present the reprint of Tarr as a new, exciting book, the firm advertised Lewis's novel alongside recent books such as Aldous Huxley's Point Counter Point (sold at 10s. and 6d.). The second kind of advertisements started appearing in Spring 1929, and focused on the Phoenix Library as a whole. In the TLS of 25 April 1929, Tarr was mentioned below The Gentle Art of Cookery. As a uniform series, the Phoenix Library did not distinguish between 'a cookery book de luxe' that 'combines literary lore with literary grace', and a modernist novel initially published for a small coterie (fig. 3a). The third group of advertisements focused only on Lewis's books. For example, a full-page ad in Lewis's review The Enemy mentioned Time and Western Man (sold at 21s.), The Art of Being Ruled (18s.), The Childermass, Section I (8s. 6d), Tarr (3s. 6d), and The Wild Body (7s. 6d). ${ }^{67}$ As the cheapest book by Lewis on the market, the Phoenix Library edition of Tarr appealed to those who were interested in his work but could not afford to spend 18 or 21 shillings on a book.

This advertising strategy was based first on the reputation of the firm Chatto \& Windus, second on the brand name of the Phoenix Library, and third on the well-known name of the author. But the novel's specific subject was not described. Instead, Chatto \& Windus followed Lewis's advice to use blurbs that praised the first edition: 'Tarr is a thunderbolt' (The Weekly Dispatch) and 'Here we have the forerunner of the prose and probably of the manner that is to come' (The New Witness). ${ }^{68}$ Rebecca West's review in The Nation also appeared on the wrap-around band shown on figure 2: 'A beautiful and serious work of art that reminds one of Dostoievsky only because it too is inquisitive about the soul, and because it contains one figure of vast moral significance which is worthy to stand beside Stavrogin.' Advertising materials thus assumed that readers had already heard of Tarr, or at least of its author. In contrast, when Alfred Knopf issued a second edition in 1926, he advertised the book as an authentic and exiting tale about Bohemian artists in Paris. 'Many novels have been written to sentimentalize and falsify them and the Latin Quarter they have made their own', declared their ad. 'None before has given the truthful picture of that intense society' (fig. 4). Knopf's ad invited curious readers to view Tarr as a quasi-sociological document on a fascinating artistic lifestyle. While Lewis was almost unknown in the United States, he needed no intro- 
duction in Britain - which explains why Chatto \& Windus's advertisements did not focus on the content of his first book.

The Phoenix Library was advertised in such literary publications as The Times Literary Supplement, The Nation and Athencum, and The Enemy, but also in more 'lowbrow' papers such as John O'London's Weekly and Everyman. According to Nash, these ads were placed by the Phoenix Book Company, which also sold the Phoenix Library and other books 'direct to the general public' by 'mail order and house-to-house visiting'. ${ }^{69}$ In fact, advertisements for the Phoenix Library appeared in John O'London's Weekly before Chatto \& Windus started working with the Phoenix Book Company. ${ }^{70}$ From its creation, the Phoenix Library was marketed as a series for a lower-middle- and middle-class audience with intellectual aspirations. In Fiction and the Reading Public, Q. D. Leavis suggested that John O'London's Weekly sold 100,000 copies per week, which then 'pass[ed] through innumerable hands in the reading-rooms of public libraries. ${ }^{71}$ ' Drawing on Leavis, Jonathan Wild speculates that 'a combined weekly readership of, say, 500,000 would not appear an unreasonable assessment. ${ }^{72}$ For many of these readers, buying books (and especially recent books) was still a luxury. Once in the Phoenix Library, modern literature became affordable for an audience eager to acquire signs of cultural capital.

The Phoenix Library was sold to a wide public in Britain, but also in continental Europe, Japan, Canada, Australia, New Zealand, and even (illegally) in the United States. In early 1928, the launch of the series was announced to major Anglophone bookshops in Paris (including Shakespeare \& Co., whose owner Sylvia Beach had published Joyce's Ulysses six years before). ${ }^{73}$ The small format of Phoenix Library books was well suited to the expatriate lifestyle. We intend to keep the series very select', wrote Harold Raymond to one bookseller in Rome. 'Their portable size should especially appeal to your clientele, many of whom I imagine "living in their boxes", or, at any rate, afraid to accumulate bulky books. ${ }^{74}$ The Phoenix Library was also available in Japan, where Chatto \& Windus was already well established (Maruzen \& Co., a bookshop in Tokyo, had one of the firm's three largest accounts outside England). Following the suggestion of a Professor of English literature at the University of Tokyo, Chatto \& Windus placed an advertisement for the Phoenix Library in Studies in English Literature (the journal of the English Literary Society of Japan) and encouraged Maruzen to stock the series. ${ }^{75}$ It shows that the Phoenix Library targeted an increasingly 
international academic market. In addition to Europe and Asia, the series was well distributed in the British dominions. As Chatto \& Windus told A. A. Milne, 'colonial buyers frequently insist on buying "cheaps" at half price. ${ }^{76}$ In Canada, therefore, the profit margin on the Phoenix Library was small. But in Australia and New Zealand, Chatto \& Windus resisted the booksellers' demand for a 50\% discount, and sold the Phoenix Library 'at ordinary English rates, which will mean owing to costs of freightage and duty the books will be retailed over there at 4s. 6d. ${ }^{77}$ In an announcement to its sales representatives in the British dominions, Chatto \& Windus reminded them to push the Phoenix Library and also to pay attention to Lewis, 'whose works are exciting very considerable attention in this country. ${ }^{78}$ The Phoenix Library edition of Tarr was therefore available in Canada (Lewis's country of birth) and the rest of the dominions. Although Chatto \& Windus did not sell the Phoenix Library in the United States, some wholesalers illegally provided the books to the trade. As Bennett Cerf - the coowner of the Modern Library - said, literally hundreds of copies of their Phoenix Library books - many of them books that are copyrighted in this country - are for sale in practically every bookstore in New York. ${ }^{79}$ Cerf had been reminded not to sell the Modern Library edition of Proust's Swann's Way in Italy (a market controlled by Chatto \& Windus), and he in turn asked Chatto \& Windus to restrict the sale of Phoenix Library books in the USA. ${ }^{80}$ It is likely, however, that Phoenix Library books continued to be sold in America, since it was difficult for publishers to prevent copies from leaking through their wholesalers.

The Phoenix Library edition of Tarr was advertised and sold to various audiences, in Britain and abroad, and it was widely reviewed an unusual fact for a reprint edition. While advertisements for the Phoenix Library appeared at all levels (from the 'lowbrow' John O'London's Weekly to the 'highbrow' Nation and Athenaum), reviews of Tarr were concentrated at the upper end of the spectrum. 'The art of choosing the right thing to reprint is almost as subtle as the art of choosing the right thing to print', declared The Sketch. 'I am glad to see that the latest edition is Mr. Wyndham Lewis's brilliant "Tarr", his first book, but, in fiction at all events, probably his best." ${ }^{\text {'1 }}$ In the Advertiser's $A B C$ (1929), The Sketch was presented as a luxurious illustrated magazine which 'sets itself to provide cheery entertainment for the smoking-room and boudoir.' ${ }^{22}$ Such literary reviews as The New Statesman (which Q. D. Leavis described as 'highbrow Labour') and the new Life \& Letters also 
reviewed the revised edition of Tarr. ${ }^{83}$ The young critic Cyril Connolly described Lewis's novel as 'an arid and untidy little picture of even more untidy and arider people': 'It seems in every way an immature book, but worth republishing, if only to reveal how well developed even then was the author's capacity for revenging himself on his associates. ${ }^{84}$ It is hardly surprising that this aggressiveness did not appeal to Connolly, who belonged to a cultural elite that Lewis detested. The Life \& Letters reviewer was more enthusiastic:

Mr. Wyndham Lewis's admirers have long been hoping for a reissue of his excellent post-war novel, Tarr. [...] Apparently, Mr. Lewis has held it back because he felt that, as it stood, the book needed re-writing; it was written hastily, he tells us, during a period of convalescence; so the new edition has been considerably enlarged and revised. After comparing the present version with what I remember of the book in its original form, I should say that the author has done his work very well indeed. I recollect having been delighted by it at a first reading some years ago, and, on looking through it again, I was once more, and as completely, subjugated by the extraordinary satiric verve which goes to its telling, the positively rhinoceros vigour with which the narrator tramples on the path he has set himself.

Interestingly, the reviewer was aware that the Phoenix Library would open up new markets for Lewis's novel: 'Tarr can be recommended not only to Mr. Lewis's usual public, but also to a wider public in search of entertainment rather than instruction - to every reader, that is to say, capable of appreciating true satire when he finds it. ${ }^{85}$ Not everybody welcomed the fact that the new Tarr was more readable and accessible to a large audience. In Apes, Japes and Hitlerism: A Study and Bibliography of Wyndham Lewis, published by a small press in 1932, John Gawsworth wrote: 'The book as it now stands possesses perhaps more literary value but one misses in it 'the cussedness and rugosities of manner' that the old Tarr possessed.' ${ }^{\prime} 6$ This inaugurated the longstanding dispute over the merits of the 1918 and 1928 texts.

Although Lewis's effort to tame his modernist style did not appeal to all his supporters, it helped him attract the attention of other cheap series of reprints. As early as 1925, Ezra Pound suggested Tauchnitz as a potential publisher. 'Of course Tauch. has up to the 
present done only reprints', wrote Pound, 'but Otto says this is not imperative. And that now that they have recovered a bit from the lyte hostilities they wd. like to do a bit-er-igh-Brow stuff. (He used much more dignified langwidge)' (P/L 146). ${ }^{87}$ Nothing came out of this proposal. But in November 1930, nearly two years after the publication of the revised Tarr, Lewis signed a contract with Tauchnitz for a cheap edition to be sold in continental Europe. He received an immediate advance of $£, 30$ for the first 8,000 copies, and the promise of $£, 10$ for each additional printing of 2,000 copies. ${ }^{8}$ For an author used to small print runs of 1,000 to 2,500 , the Tauchnitz edition was the key to a much broader market. The fact that Tauchnitz based its edition on the 1928 text highlights the importance of the Phoenix Library in the diffusion of Lewis's novel. This expanding market for Tarr was both vertical (from 'high' to 'lowbrow') and spatial, since the revised text was now available in two cheap editions in Europe and in the whole British Empire. In 1948, Penguin made an offer for a paperback publication of Tarr - 'the novel was to be issued in an edition of not fewer than 50,000 copies, to be sold at 2s. ${ }^{89}$ The publisher was undoubtedly aware that the book had been a commercial success in the Phoenix Library, and wanted to sell it to the mass market. Although Penguin eventually dropped its offer, this episode shows the importance of the Phoenix Library in bringing Tarr to the attention of new audiences. ${ }^{90}$

In 1950, the Phoenix Library (which had gone out of print during the Second World War) was re-launched with titles such as Woolfs Mrs Dalloway and Aldous Huxley's After Many a Summer. 'Do you remember those gay little volumes, red with a stylized phoenix in white, which stood on every sensible undergraduate's bookshelf?', asked the magazine Time \& Tide. 'Lytton Strachey, C. E. Montague and Aldous Huxley figured largely as their authors and most people read Tarr in this edition. ${ }^{91}$ There are two interesting points here: first, the fact that the original Phoenix Library was read by students (at the time when modernism was being institutionalized in academia), and second, the attribution of Tarr's expanding readership to the series. ${ }^{92}$ More than two decades after the publication of the revised Tarr, the Phoenix Library continued to be praised for making the book available to a broader audience. By that time, however, Lewis had long dissociated himself from Chatto \& Windus. He once wrote to his old friend William Rothenstein: it was very unwise of me to allow my books to pass into the hands of the official 'Bloomsbury' publisher.' ${ }^{93}$ The year the New 
Phoenix Library was launched, Lewis's biography Rude Assignment was published under the Hutchinson imprint. 'I am what is described as a "highbrow" ( $\mathrm{R} A$ 15), wrote Lewis, before deploring the gap between the cultural extremes: 'The invisible line separating the two Publics cannot be crossed with impunity by one of the Minority' ( $\mathrm{A} A$ 20). The publication of Tarr in the Phoenix Library ('an aristocrat among pocket libraries') was one of the rare moments when Lewis did cross this line to reach all kinds of readers - the 'aristocratic audience' he desired but also the 'lowbrow' readers of John O'London's Weekly and Everyman. 


\section{Images}

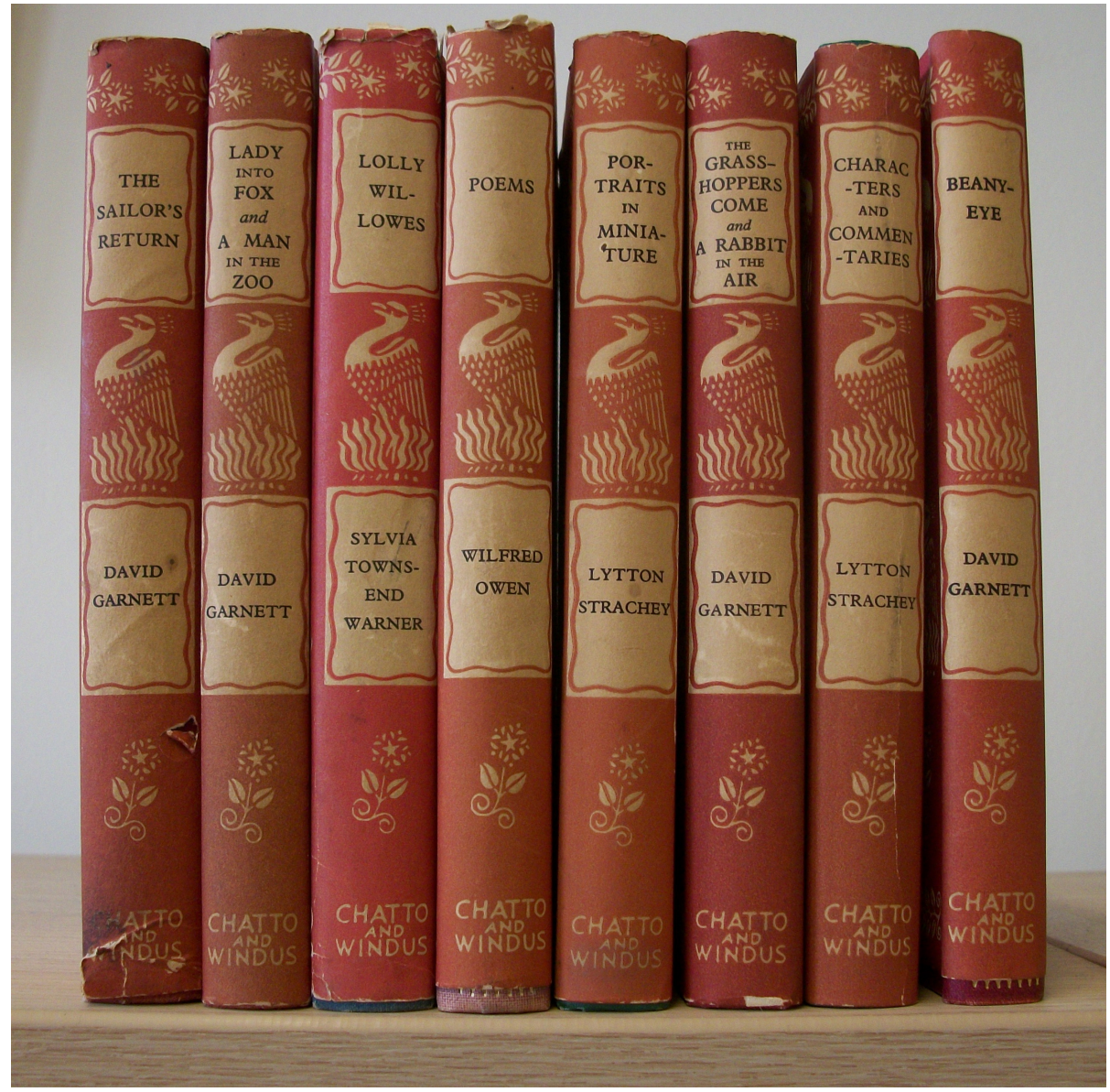

Fig. 1: Phoenix Library books, with dust jacket designed by Thomas Derrick. Photograph provided by author. 


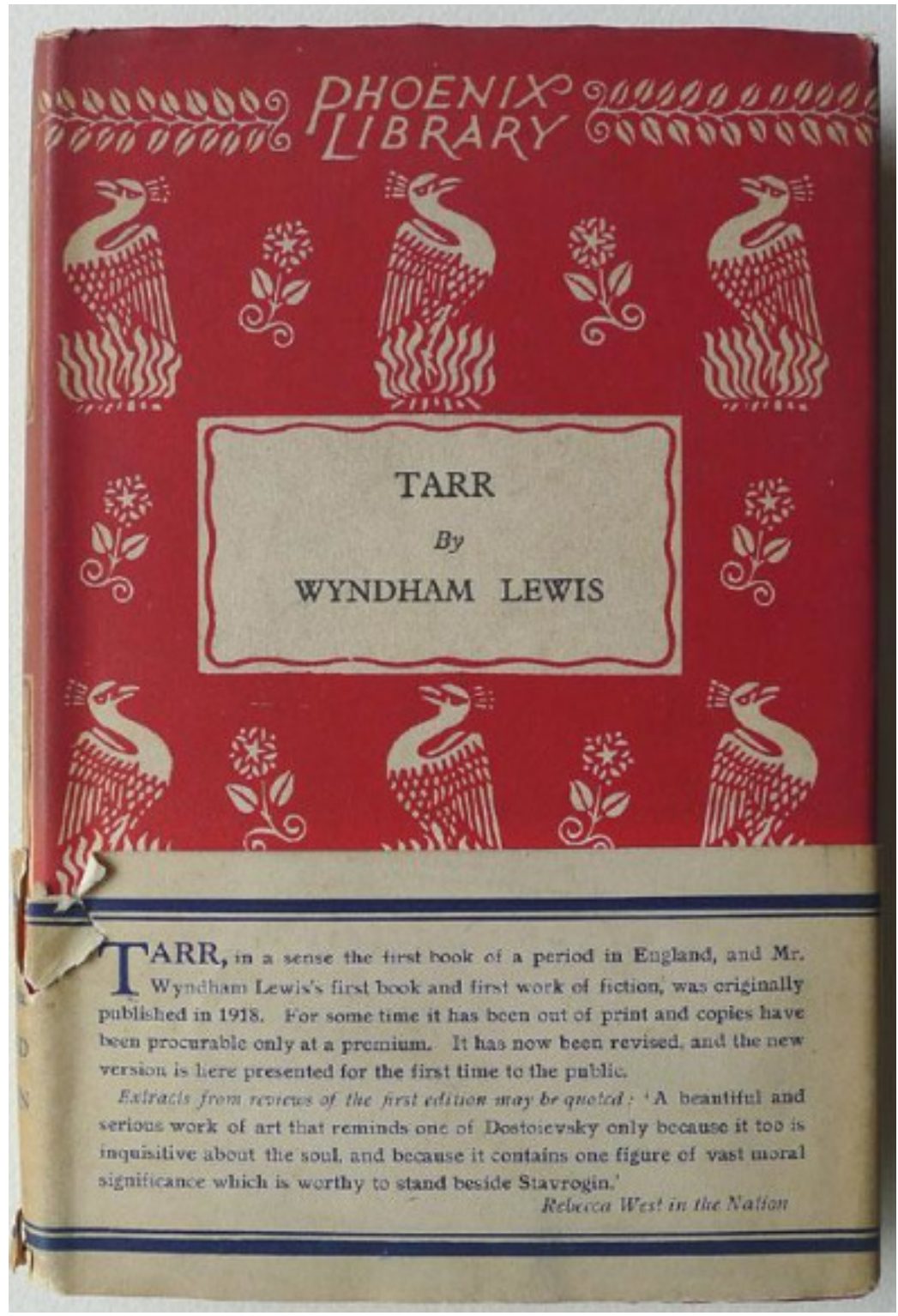

Fig. 2: Dust jacket of Tarr (1928 Phoenix Library ed.), with wrap-around band. Photograph provided by author. 

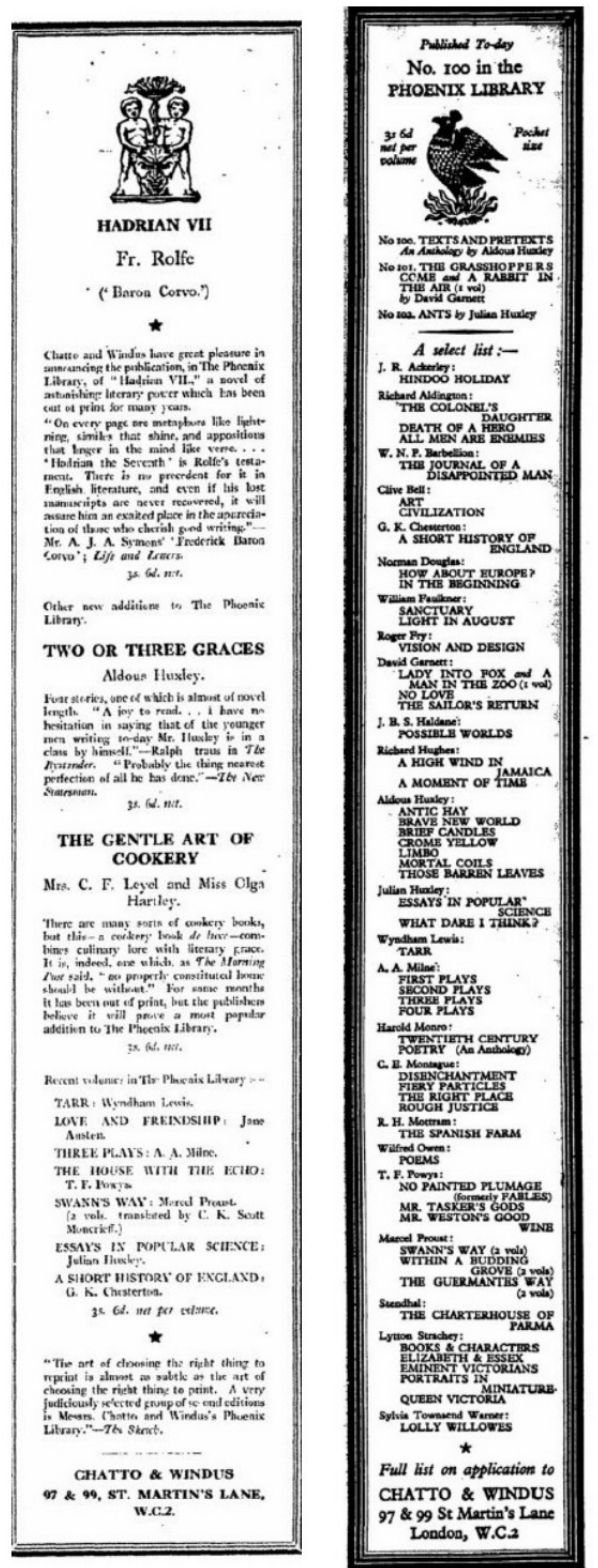

Fig. 3: Advertisements for the Phoenix Library, Times Literary Supplement (a) 25 April 1929: 334 and (b) 21 Feb. 1935: 100. 


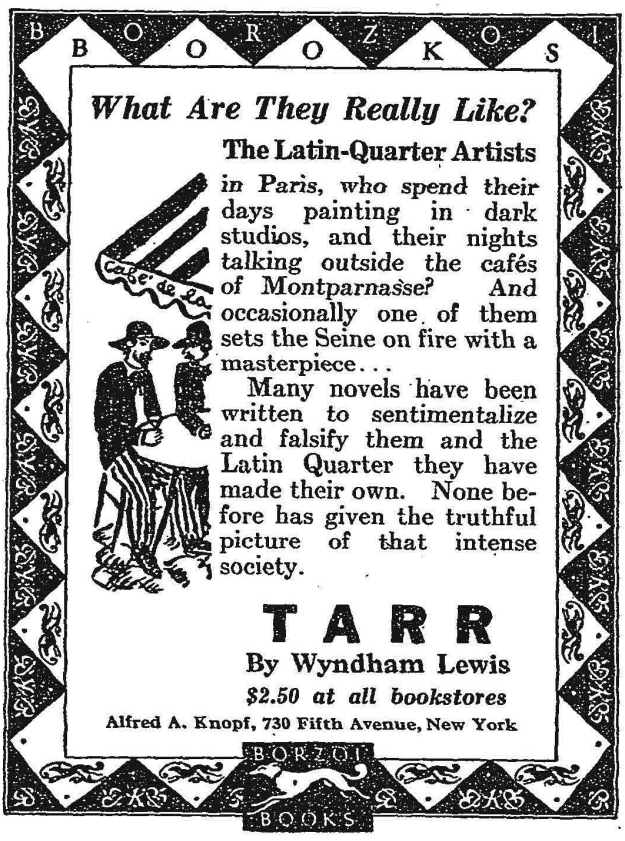

Fig. 4: Advertisement for Tarr (Knopf ed.), New York Times 18 July 1926: BR20.

\section{Notes}

${ }^{1}$ John Xiros Cooper, Modernism and the Culture of Market Society (Cambridge: Cambridge University Press, 2004), 215.

2 For relevant accounts see O'Keeffe's and Klein's editorial commentaries in T1 and T2, respectively, as well as Stephen Sturgeon's doctoral thesis, 'Wyndham Lewis's Tarr. A Critical Edition' (Boston University Graduate School of Arts and Sciences, 2007).

${ }^{3}$ Sturgeon, 'Wyndham Lewis's Tarr', 23.

4 Andrew Nash, 'Literary Culture and Literary Publishing in Inter-War Britain: A View from Chatto \& Windus', in Simon Eliot, Andrew Nash, and I. R. Willison (eds), Literary Cultures and the Material Book (London: British Library, 2007): 323-42, at 337.

5 Andrew Nash, 'Sifting Out "Rubbish" in the Literature of the Twenties and Thirties: Chatto \& Windus and the Phoenix Library', in John Spiers (ed.), The Culture of the Publisher's Series - Volume 1: Authors, Publishers, and the 
Shaping of Taste (Basingstoke: Palgrave Macmillan, 2011): 188-201, at 191 and 199.

${ }^{6}$ Lawrence Rainey, Institutions of Modernism: Literary Elites and Public Culture (New Haven, CT: Yale University Press, 1998), 38.

7 Paul O'Keeffe, Some Sort of Genius: A Life of Wyndham Lewis (London: Jonathan Cape, 2000), 189.

${ }^{8}$ Cooper, Modernism and the Culture of Market Society, 215.

9 Jeffrey Meyers, The Enemy: A Biography of Wyndham Lewis (London: Routledge \& Kegan Paul, 1980), 85.

10 Jane Lidderdale and Mary Nicholson, Dear Miss Weaver: Harriet Shaw Weaver 1876-1961 (London: Faber and Faber, 1970), 464.

${ }^{11}$ In 1926, Knopf issued a second edition priced at $\$ 2.50$. The book had previously been out of print. See C. Hartley Grattan, 'In the Pages of Books' [Review of Tarr], Evening Independent [St. Petersburg, Florida] (14 August 1926): 3.

12 T. S. Eliot, 'Tarr', The Egoist (September 1918): 106.

13 The Egoist Ltd Extracts from Press Notices of Tarr, MS 57355, Harriet Shaw Weaver papers, British Library.

14 Paul Edwards, Wyndham Lewis: Portraits (London: National Portrait Gallery, 2008), 33.

15 Meyers, The Enemy, 135.

16 Andrew Nash and James Knowlson, 'Charles Prentice and T. F. Powys: A Publisher's Influence', The Powys Journal 12 (2002): 35-66, at 35. For Aldington, Prentice was 'the ideal publisher, a scholar whose advice in literary matters was of great value and a man of such gentle sweetness and charm that I came to feel the greatest affection for him'. See Richard Aldington, Life for Life's Sake: A Book of Reminiscences (New York: Viking Press, 1941), 353.

17 See Beverly Schneller, 'Chatto and Windus; John Camden Hotten', in Patricia Anderson and Jonathan Rose (eds), British Literary Publishing Houses, 1820-1880 (Detroit: Gale Research, 1991).

18 Prentice to Huxley, 3 November 1927, Letter book, CW A/119, Chatto $\&$ Windus archive, University of Reading.

${ }^{19}$ Chatto \& Windus to Pinker, 2 November 1927, Letter book, CW A/119.

20 A five-shilling leather edition, 'uniform in a smooth rich crimson', was advertised in 1928 (see, for example, advertisement for the Phoenix Library, The Observer (29 January 1928): n.p.). A 1931 letter refers to 'the now defunct Phoenix Library leather edition' (Phoenix Book Co. to Harold Raymond, 6 March 1931, Letters from The Phoenix Book Company, CW $41 / 5)$. 
21 www.nationalarchives.gov.uk/theartofwar/artists/derrick thomas.htm 'Derrick, Thomas', National Archives (accessed 9 January 2014).

22 Phoenix Library leaflet, 1928, Advertisements book, CW D/5.

${ }^{23}$ Chatto \& Windus to TLS Editor, 17 January 1928, Letter book, CW A/119.

${ }^{24}$ CW to Pinker, 2 November 1927, Letter book, CW A/119.

${ }^{25}$ Jay Satterfield, The World's Best Books: Taste, Culture, and the Modern Library (Amherst: University of Massachusetts Press, 2002), 93.

${ }^{26}$ Chatto \& Windus to TLS Editor, 17 January 1928, Letter book, CW A/119.

${ }^{27}$ Nash, 'Sifting Out "Rubbish", 190.

${ }_{28}$ Prentice to C. F. Leyel, 7 November 1928, Letter book, CW A/122.

${ }^{29}$ Raymond to G. O. Anderson (George H. Harrap \& Co.), 22 November 1928, Letter book, CW A/122.

${ }^{30}$ Chatto \& Windus to Fry, 15 December 1927, Letter book, CW A/119.

${ }^{31}$ Stock book 9, CW B/2/20.

32 Ibid.

33 Dominic Hibberd, 'Monro, Harold Edward (1879-1932)', The Oxford Dictionary of National Biography (Oxford: Oxford University Press, 2004). Accessed 3 January 2014.

34 Dominic Hibberd, Harold Monro: Poet of the New Age (Basingstoke: Palgrave, 2001), 144.

35 Harold Monro, 'Introduction', Twentieth Century Poetry: An Anthology (London: Chatto and Windus (Phoenix Library), 1929): 7-11, at 10.

${ }^{36}$ Owen's Poems, with an introduction by Edmund Blunden, appeared in the Phoenix Library in 1933. 6,000 copies of this edition were printed from June 1933 to March 1939 (Stock book 9, CW B/2/20). This edition thus reached a much wider audience than the 1920 anthology of his work, edited by Sassoon. See Daniel Todman, The Great War: Myth and Memory (London: Hambledon and London, 2005), 162.

${ }^{37}$ Pound quoted in Joy Grant, Harold Monro and the Poetry Bookshop (London: Routledge \& Kegan Paul, 1967), 161.

38 'The Best Anthology', The Morning Post (13 December 1929): n.p.

39 Arnold Bennett, 'Thousands Argue About the Modern Novel - But the Revolutionary Poetry of To-Day is Left Out of Conversation', The Evening Standard (12 December 1929): n.p. Reprinted in Arnold Bennett, The Evening Standard Years: Books and Persons' 1926-1931, ed. Andrew Mylett (London: Chatto \& Windus, 1974), 332. 
${ }^{40}$ Richard Aldington described Bennett as 'the only English reviewer in my experience who could induce people to read the books he praised'. See Aldington, Life for Life's Sake, 344.

${ }^{41}$ Prentice to Monro, 23 November 1927, Letter book, CW A/119.

42 Stock book 9, CW B/2/20.

${ }^{43}$ Grant, Harold Monro, 162.

44 'The two Phoenix names were coincidental. See Nash, 'Literary Culture', 337.

45 Phoenix Book Co. Catalogue (my emphasis), Letters from The Phoenix Book Company, 1930-1931, CW 41/5.

${ }^{46}$ See N. N. Feltes's distinction between 'list' and 'enterprising' publishers in Literary Capital and the Late Victorian Novel (Madison, WI: University of Wisconsin Press, 1993), 25-34.

${ }^{47}$ Nash and Knowlson, 'Charles Prentice and T. F. Powys', 57.

48 Arnold Bennett, 'An Artist Turned Author - Mr. Wyndham Lewis', The Evening Standard (28 April 1927): n.p. Reprinted in Bennett, The Evening Standard Years, 44.

${ }^{49}$ Lewis to Editor, The Evening Standard, 6 May 1927, box 64, folder 93, Wyndham Lewis collection, Cornell.

${ }^{50}$ Lewis to Prentice, 18 May 1928, Correspondence between Wyndham Lewis and Chatto \& Windus, CW 144/3.

51 'The novel will rival "Ulysses" in scale: in scope it is far wider' (The Nation). This blurb appeared in an advertisement for The Childermass (Section I), published in The New Statesman (30 June 1928): 395.

52 Prentice to Lewis, [18?] May 1928, Correspondence between Wyndham Lewis and Chatto \& Windus, CW 144/3.

53 Ibid.

${ }^{54}$ Contract for the Phoenix Library ed. of Tarr, 29 May 1928, Random House Group Archive, Rushden.

${ }_{55}$ Cooper, Modernism and the Culture of Market Society, 218.

${ }^{56}$ Lewis to Prentice, 17 Nov. 1928, Correspondence between Wyndham Lewis and Chatto \& Windus, CW 144/3. See also T2.

57 See Lise M. Jaillant, Modernism, Middlebrow and the Literary Canon: The Modern Library Series, 1917-1955 (London: Pickering \& Chatto, 2014), 85-86.

${ }^{58}$ Prentice to Lewis, 9 June 1928, Letter book, CW A/121.

${ }^{59}$ Chatto \& Windus to F. A. Mumby, 28 June 1928, Letter book, CW A/121.

${ }^{60}$ Chatto \& Windus to Mumby, 28 June 1928, Letter book, CW A/121.

${ }^{61}$ 'They are an admirable series to collect and to go on collecting'. Advertisement for the Phoenix Library, The Observer (29 January 1928): n.p. 
${ }^{62}$ Lewis to Prentice, 27 August 1928, Correspondence between Wyndham Lewis and Chatto \& Windus, CW 144/3.

${ }^{63}$ Prentice to Lewis, 6 December 1928, Letter book, CW A/122; Stock book $9, \mathrm{CW} \mathrm{B/2/20.}$

${ }^{64}$ Stock book 9, CW B/2/20. See also Bradford Morrow and Bernard Lafourcade, A Bibliography of the Writings of Wyndham Lewis (Santa Barbara: Black Sparrow Press, 1978), 34; and Omar S. Pound, Philip Grover, and D. G. Bridson, Wyndham Lewis: A Descriptive Bibliography (Folkestone: Dawson, 1978), 7 and 9.

65 See The Times Literary Supplement (13 December 1928): 979; (31 January 1929): 70; (21 February 1929): 126; (25 April 1929): 334; (6 June 1929): 452.

66 The Times Literary Supplement (31 January 1929): 70.

${ }^{67}$ The Enemy, c. 1929, Advertisement book, CW D/6.

68 Lewis to Prentice, 1 December 1928, Correspondence between Wyndham Lewis and Chatto \& Windus, CW 144/3.

${ }^{69}$ Nash, 'Literary Culture', 337.

${ }^{70}$ See for example, advertisement for the Phoenix Library, John O'London's Weekly (17 March 1928): n.p. Chatto \& Windus started working with the Phoenix Book Company in early 1931. Shortly after, the Company asked Chatto \& Windus for the permission to place advertisements in Everyman and John O'London Weekly ('Do you think there would be any objection sufficient to cause you embarrassment from the trade if we do this?'). Phoenix Book Co. to Harold Raymond, 20 April 1931, Letters from The Phoenix Book Company, CW 41/5.

${ }^{71}$ Q. D. Leavis, Fiction and the Reading Public (1932; London: Chatto and Windus, 1939), 20-21.

72 Jonathan Wild, “Insects in Letters": John O'London's Weekly and the New Reading Public', Literature \& History 15. 2 (2006): 50-62, at 59.

${ }^{73}$ Chatto \& Windus to Galignani Library, 3 February 1928, Letter book, CW A/120 (includes the following note: 'A copy of this letter sent to Miss S. Beach, Shakespeare \& Co., Paris \& Messrs Brentano's, Paris').

${ }^{74}$ Raymond to Miss Grimes (Wilson's Library), 26 January 1928, Letter book, CW A/119.

75 Chatto \& Windus to Arundell del Re, 11 November 1927; Chatto \& Windus to Maruzen, 11 November 1927, Letter book, CW A/119.

${ }^{76}$ Chatto \& Windus to Milne, 3 November 1927, Letter book, CW A/119.

77 Chatto \& Windus to Roger Fry, 15 December 1927, Letter book, CW A/119.

${ }^{78}$ Chatto \& Windus to G. J. Hicks \& Co., 5 January 1928; Chatto \& Windus to G. J. McLeod Ltd, 5 January 1928, Letter book, CW A/119. 
${ }^{79}$ Cerf to Alma Levin (Brandt \& Brandt), 29 May 1929, box 99, Random House records, Columbia.

${ }^{80}$ Cerf to Bernice Baumgarten (Brandt \& Brandt), 7 June 1929, box 99, RH.

81 The Sketch (6 February 1929): n.p.

${ }^{82}$ Quoted in Leavis, Fiction and the Reading Public, 277.

83 Ibid., 182.

${ }^{84}$ The New Statesman 5 January 1929: n. pag. Tarr was Number 29 on Connolly's list of 100 key books from 1880 to 1950. See Cyril Connolly, The Modern Movement: One Hundred Key Books from England, France and America 1880-1950 (London: André Deutsch; Hamish Hamilton, 1965), 34-35.

${ }^{85}$ Life \& Letters (May 1929): n.p.

${ }^{86}$ John Gawsworth, Apes, Japes and Hitlerism: A Study and Bibliograpby of Wyndham Lewis (London: Unicorn Press, 1932), 43.

${ }^{87}$ The 'Otto' that Pound mentions is Curt Otto, the head of the firm.

${ }^{88}$ Contract for the Tauchnitz edition of Tarr, box 60, folder 45, Wyndham Lewis collection, Cornell.

${ }^{89}$ Morrow and Lafourcade, Bibliography, 36.

90 Similarly, the fact that the Modern Library reprinted Sherwood Anderson's Winesburg, Ohio (a book first published by the small press of Ben Huebsch) brought it to the attention of Penguin, which published a paperback edition in 1946 with a first printing of 150,000. See Jaillant, Modernism, Middlebrow and the Literary Canon, 41-62.

${ }^{91}$ Time \& Tide (10 February 1951): n.p.

${ }_{92}$ F. R. Leavis was of course instrumental in the institutionalization of modernist studies from the 1930s. See Christopher Hilliard, English as a Vocation: The 'Scrutiny' Movement (Oxford: Oxford University Press, 2012); and Francis Mulhern, The Moment of 'Scrutiny' (London: NLB, 1979).

${ }^{93}$ Lewis to Rothenstein, 30 November 1938, box 68, folder 52, Wyndham Lewis collection, Cornell. 